Atlantic Deep Water. The initial $0^{18 / 0^{16}}$ of the Mediterranean surface waters would be expected to be free of influence from the Atlantic source. Subsequent excess evaporation in the Mediterranean would increase the $\delta \mathrm{O}^{18}$ of the surface waters. The observed progressive decrease in the $\delta 0^{18}$ of the carbonate from $+32 \%$ to $+31 \%$ could only be brought about if temperature effects overrode those of the isolation. Consequently the $4^{\circ}$ to $5^{\circ} \mathrm{C}$ inferred warming is a minimum value.

From the Late Pliocene to the Pleistocene, there is a 1.5 to $2 \%$ increase in the $\delta \mathrm{O}^{18}$ of $\mathrm{CaCO}_{3}$. If no large isotopic changes had taken place as a result of diagenesis, this could be attributed to: (a) an increase in the $\delta \mathrm{O}^{18}$ of the surface waters of 1.5 to $2 \%$ as a result of progressive isolation of the Mediterranean from the Atlantic (see Chapter 47.4), (b) to a cooling of the surface waters by $6^{\circ}$ to $9^{\circ} \mathrm{C}$, or (c) to a combination of both factors. It is probable that both cooling and an increase in the $\delta 0^{18}$ of the surface waters occurred with an increase in glaciation. An increase in glaciation is consistent with dropping temperatures. But also, increased glacial uptake of water would drop sea level and decrease circulation between the Atlantic and the Mediterranean. Increased isolation of the Mediterranean would have a greater effect on increasing the $018 / 0^{16}$ of the Mediterranean surface waters.
The variations in $0^{18 / O^{16}}$ and $\mathrm{C}^{13} / \mathrm{C}^{12}$ of the bulk carbonate at Site 132 are consistent with changes in surface water temperatures or with $\mathrm{O}^{18} / \mathrm{O}^{16}$ and $\mathrm{C}^{13} / \mathrm{C}^{12}$ variations in the surface waters as inferred from physical or paleontological changes in the sediment. In addition, sharp changes in $\mathrm{O}^{18 / \mathrm{O}^{16}}$ and $\mathrm{C}^{13} / \mathrm{C}^{12}$ occur over short time intervals in the sediments. Isotopic exchange or recrystallization of the bulk carbonate would tend to smooth such sharp isotopic gradients. These facts suggest that the isotopic values of most of the carbonate, with the exception of the Miocene sediments, is largely unaffected by diagenesis. Isotopic studies on individual carbonate fossils should verify this and determine to what degree changes in biologic makeup of the carbonate portion of the sediments (ignored in this discussion) have determined the $0^{18 / 0^{16}}$ and $\mathrm{C}^{13} / \mathrm{C}^{12}$ of the bulk carbonate.

Lamont-Doherty Geological Observatory Contribution No. 1860 .

\section{REFERENCES}

Epstein, S., Buchbaum, R., Lowenstam, H. A. and Urey, H. C., 1953. Revised carbonate-water isotopic temperature scale. Bull. Geol. Soc. Am 64, 1315.

McCrea, J. M., 1950. The isotopic chemistry of carbonates and a paleotemperature scale. J. Chem. Phys. 18, 849.

\title{
30.4. OXYGEN ISOTOPIC COMPOSITION OF BENTHONIC AND PLANKTONIC FORAMINIFERA OF EARLIEST PLIOCENE AGE AT SITE 132 - TYRRHENIAN BASIN
}

\author{
J. Van Donk and T. Saito, Lamont-Doherty Geological Observatory of Columbia University, Palisades, New York \\ and \\ N. J. Shackleton, Sub-Department of Quaternary Research, University of Cambridge, Cambridge, England
}

\section{INTRODUCTION}

Although it has been shown that some foraminifera do not deposit calcium carbonate in isotopic equilibrium with the surrounding water, the deviations noted are relatively small (up to $-1.0 \%$ ). For this reason it was considered worthwhile to analyse specimens of both benthonic and planktonic foraminifera from a single sample of pelagic ooze of earliest Pliocene age from Site $132\left(40^{\circ} 15.7^{\prime} \mathrm{N}\right.$; $11^{\circ} 26.5^{\prime} \mathrm{E}$, depth $2835 \mathrm{~m}$ ). It was hoped to obtain information about the structure of the Mediterranean water mass following re-introduction of marine conditions at the end of the late Miocene "crisis of salinity".

A quarter core section from 52 to $75 \mathrm{~cm}$ in Section 4 of Core 20 was sampled and washed. The sample interval is from a level only a few meters above the Miocene/Pliocene boundary (see Chapter 47 ).

\section{RESULTS}

\section{Benthonic Foraminifera}

The sample of benthonic foraminifera had a weight of about micrograms. It was roasted in vacuo before analysis at the University of Cambridge. Carbon dioxide was released by the action of 100 per cent orthophosphoric acid in vacuo at $50^{\circ} \mathrm{C}$, and it was analysed in a double-collecting mass spectrometer. Results were calibrated by the analysis of standard carbonates in identical conditions. The result (relative to the PDB standard) was:

$$
\begin{aligned}
& \delta \mathrm{O}^{18}=(+0.3 \pm 0.1)^{\circ} \% \\
& \delta \mathrm{C}^{13}=(+0.7 \pm 0.1)^{\circ} \%
\end{aligned}
$$

The analytical method is routine in this laboratory; the quoted uncertainty represents the standard deviation 
among replicate analyses of small samples of calcium carbonate under the same conditions $(1-\sigma)$.

\section{Planktonic Foraminifera}

Two species of foraminifera, Globigerina bulloides and Sphaeroidinellopsis seminulina were isolated from the washed residues and analysed separately. The specimens were crushed and then shell fragments were washed ultrasonically to remove any chamber fillings present. They were then vacuum dried at room temperature. The carbonate material was reacted with 100 per cent orthophosphoric acid in vacuo at $25^{\circ} \mathrm{C}$ without having been roasted. The analysis was carried out in the Geochemistry Laboratory of the Lamont-Doherty Geological Observatory in a doublecollecting mass spectrometer, and, as in the case of the benthonic foraminifera, the results are reported with respect to the PDB standard.

$$
\begin{array}{ll}
\text { G. bulloides } & \delta \mathrm{O}^{18}=(+1.0 \pm 0.15) \% \\
\delta \mathrm{C}^{13}=(+0.3 \pm 0.15) \% \\
\text { S. seminulina } & \delta \mathrm{O}^{18}=(+0.4 \pm 0.03) \% \\
\delta \mathrm{C}^{13}=(+1.39 \pm 0.09) \%
\end{array}
$$

Measurements on the specimens of Sphaeroidinellopsis seminulina are considered to be the most reliable. Results shown above are an average of three separate analyses. The sample comes from the Sphaeroidinellopsis Acme-zone (see Chapter 47.1) where this taxon sometimes comprises up to 70 per cent of the foraminifera population. The substantial number of tests of Globigerina bulloides seems to suggest cold temperatures of the surface waters since, according to Bé and Tolderlund (1971), this is a dominant species in subarctic and subantarctic waters with a peak abundance in water masses having a temperature range of from $3^{\circ}$ to $19^{\circ} \mathrm{C}$.

\section{DISCUSSION}

The most obvious, and probably the most significant, observation is that the oxygen isotopic composition of the benthonic foraminifera is extremely close to that of the planktonic foraminifera. The higher value of $+1.0 \%$ from Globigerina bulloides perhaps indicates that this taxon lived at shallower depths in the surface water layer than Sphaeroidinellopsis seminulina (personal communication, M. B. Cita). At these depths the $\mathrm{O}^{18}$ content is slightly enriched as the result of evaporation and higher salinity. ${ }^{1}$

It is somewhat hazardous to translate the $\delta \mathrm{O}^{13}$ values directly to paleotemperatures without knowledge of the isotopic composition of the Mediterranean water mass of early Pliocene age. The value of +0.3 would correspond to a temperature of about $15^{\circ} \mathrm{C}$ if the fossil tests were in isotopic equilibrium with present day North Atlantic Deep Water. ${ }^{2}$ The true value would be lower by a few degrees, at most, if the species analysed did not deposit carbonate in

\footnotetext{
${ }^{1}$ The oxygen isotope composition of the surface layer of the Caribbean is measurably heavier than that of the bottom water for the same reason (Craig and Gordon, 1965).

${ }^{2}$ According to Craig and Gordon (1965) North Atlantic Deep Water has a present composition of $+0.1 \%$ (SMOW).
}

isotopic equilibrium. It would also be lower if account were taken of a change in the isotopic composition of the oceans such as the one which would result from a reduction in the amount of ice on Antarctica. This last correction may perhaps be ignored for Pliocene material.

At present the surface and deep waters in the Mediterranean have an isotopic composition about $1.2 \%$ heavier than North Atlantic Deep Water in consequence of the excess evaporation (Epstein and Mayeda, 1953; corrected by Craig and Gordon, 1965). Benthonic foraminifera living at $13^{\circ} \mathrm{C}$ today would be expected to have an isotopic composition of about $+2.0 \%$. The Pliocene sample analysed would represent a temperature of around $21^{\circ} \mathrm{C}$ in present-day Mediterranean water, an improbably high value. However, a lower temperature than this would be derived if the salinity excess were much less than today as the consequence of a more open exchange with the Atlantic Ocean.

If we allow ourselves to examine the working hypothesis of a more open exchange in early Pliocene times between the Mediterranean and the Atlantic (see Chapter 47.4), we also have to ask how this exchange was initiated in the first place. After all, during the late Miocene evaporite deposition, the passageway, to all intents and purposes, was blocked.

From stratigraphic considerations (see Chapters 47.1 and 47.2), the Mediterranean sample of pelagic ooze investigated here was deposited within approximately 100,000 years after the first truly effective opening of the Gibraltar portal, this opening established permanent open marine conditions in the Mediterranean. The isotopic value of $\delta \mathrm{O}^{18}=0.3$ for the benthonic foraminifera could imply that the Mediterranean then communicated with the Atlantic over a sill at a depth corresponding to a temperature of about $15^{\circ} \mathrm{C}$ or a little less, and that bottom water in the Mediterranean entered over this sill. This implies a wide enough sill to permit free exchange in both directions.

The similarity of the isotopic composition of the planktonic and benthonic foraminifera indicates a thermal homogeneity in the Mediterranean water structure. A speculative model which would account for both the similarity in the oxygen isotopic composition of the planktonic and benthonic foraminifera and its composition at 0.3 to $0.4 \%$, invokes a catastrophic flooding of the Mediterranean basins following the late Miocene evaporite epoch. In this model, water entering the Mediterranean would be comprised of both cold North Atlantic Deep Water (down to the level of the sill eroded away) and warmer surface water, well mixed as it poured into the partially desiccated basin (see Chapter 43). The oozes in Section 4 of Core 20 at Site 132 could have been deposited either while the basin was still flooding or before it established a steady-state thermocline.

The depth of the sill at Gibraltar necessary to produce a water column in the Mediterranean with a mean temperature of around $15^{\circ} \mathrm{C}$ is extremely difficult to estimate. There is evidence, though, that bottom water temperatures in the open oceans were warmer in early Pliocene times than they are today.

From similar measurement of benthonic foraminifera in cores from the Pacific Ocean, Emiliani (1954) reported a cooling trend in the Pacific Bottom Waters from $10.4^{\circ} \mathrm{C}$ in 
the middle Oligocene to $7.0^{\circ} \mathrm{C}$ in early-middle Miocene to $2.2^{\circ} \mathrm{C}$ in the late Pliocene. We have been able to substantiate that this cooling trend also was present in the Atlantic Ocean. A study by two of us (T.S. and J.V.D.) of the isotopic composition of benthonic foraminifera of late Miocene and early Pliocene age in DSDP cores from the South Atlantic (Site 15 at $31^{\circ} \mathrm{S}$ ) reveals that the Atlantic waters were as warm as $5^{\circ} \mathrm{C}$ at the time the pelagic oozes were deposited in Core 20 of Site 132.

The present day mean surface water temperature of the Atlantic west of Gibraltar is $22^{\circ} \mathrm{C}$ in August. It reaches $24^{\circ} \mathrm{C}$ in the Mediterranean near Site 132. Since flooding, therefore, would have had to involve a considerable amount of North Atlantic deep water to bring the average temperature down to $15^{\circ} \mathrm{C}$, we can roughly infer that the incision of Gibraltar might have been as deep as 1000 meters in order to effect the required exchange.

We can conclude that, although the measurement of benthonic foraminifera alone does not exclude the possibility of bottom water formation locally within the Pliocene Mediterranean, the measurements on both the benthonic and planktonic foraminifera can be more easily understood in terms of entry of water into the Mediterranean from the Atlantic over a sill at Gibraltar of appreciable depth and width.

\section{ACKNOWLEDGMENTS}

The study was initiated at the suggestion of William B. F. Ryan. Discussions with K. J. Hsü, who carried the samples from Lamont to Europe, have been very helpful. The research at Lamont-Doherty Geological Observatory has been supported by National Science Foundation grant GA 28507. Lamont-Doherty Geological Observatory Contribution Number 1809.

\section{REFERENCES}

Bé, A. W. H. and Tolderlund, D. S., 1971. Distribution and ecology of living planktonic foraminifera in surface waters of the Atlantic and Indian Oceans. In Micropaleontology of Oceans; Funnell, B. M. and Riedel, W. R., (Editors), Cambridge University Press, London, 105.

Craig, H. and Gordon, L. I., 1965. Isotopic Oceanography: Deuterium and Oxygen 18 variations in the ocean and the marine atmosphere. Proc. of the Symposium on Marine Geochemistry; The University of Rhode Island, Occasional Publication No. 3, 277.

Emiliani, C., 1954. Temperatures of Pacific Bottom Waters and Polar Superficial Waters during the Tertiary. Science. 119, (3013), 853.

Epstein, S. and Mayeda, T., 1953. Variation of $\mathrm{O}^{18}$ Content of Waters from natural sources. Geochim. Cosmochim. Acta, 4, 213. 